\title{
Antikitenin Öğrettikleri: Yeni Çağ Avrupa Düşüncesinde Yeni Stoacılık
}

\author{
M. Burak Özdemir*, Fatih Durgun**
}

\begin{abstract}
Öz: Aşağıda da tartışılacağı gibi, özellikle Rönesans ve Reformasyon dönemlerinden itibaren stoacı felsefenin dönemin olumsuzluklarına antik mirasın diğer birçok öğesinden daha iyi çözüm önerdiğine inanılmıştır. Çoğunlukla bu felsefeyle özdeşleştirilen isimlere atıfta bulunularak oluşturulan söylemler, hem düşünsel tartışmalara hem de daha somut siyasi ve düşünsel programlara yön vermiştir. Bu yazıda da esasen, yeni stoacılık olarak tanımlanan düşünsel faaliyetin Yeni Çağ Avrupa tarihinde, sosyal, ekonomik, dinsel ve politik yıkımlar neticesinde ortaya çıkmaya başlayan merkezî devlet yönetimleri bünyesindeki yeri tartışılacaktır. Genel olarak bu merkezî yapılanmaların, bir antik çağ mirasının, o dönem merkezî oluşumlarının içerisinde ne kadar da önemli olduğunu göstermek amaçlanmaktadır.
\end{abstract}

Anahtar Kelimeler: Antikite, Yeni Stoacılık, Justus Lipsius, Seneca, Tacitus, Rönesans, Reform, Yeni Çağ.

\begin{abstract}
Early Modern Europe witnessed the emergence of more centralised states as a consequence of socio-political, economic and religious turmoil. Since Renaissance and Reformation, it has been commonly held that Stoic philosophy has offered much more solid solutions to the problems of the crises in Western societies rather than the other philosophical schools of the Antiquity. This paper argues that the discourses shaped by references to the thinkers identified with Neo-Stoicism steered the course of intellectual discussions as well as political and intellectual programmes in this period. Besides, the place and influence of Neo-Stoicism, as an ancient philosophical school, in the formation of early modern central states should be emphasized.

Key Words: Antiquity, Neo-Stoicism, Justus Lipsius, Seneca, Tacitus, Renaissance, Reformation.

* Araştırma Görevlisi., Belfast Queen's Üniversitesi Tarih Bölümü. m_burak19@hotmail.com

** Araştırma Görevlisi., Bilkent Üniversitesi Tarih Bölümü. fatihd@bilkent.edu.tr

Atıf@: Özdemir, B., Durgun, Fatih. (2009). Antikitenin Öğrettikleri: Yeni Çağ Avrupa Düşüncesinde Yeni Stoacilık. insan ve Toplum, 1 (1), 25-44.
\end{abstract}


Aydınlanma düşünce geleneği içinde Aristoteles ve Platon'un metinleri üzerinden yapılan tartışmaların yeni stoacılık gibi antikite kökenli düşünce ekollerini marjinalleştirmiş olabileceği varsayılsa da Yeni Çağ ve sonrasında, bir düşünce ekolü olarak yeni stoacılık, siyaset ve toplum tasavvurları üzerinde belirleyici bir konumda olmuştur. Türkiye'den Avrupa tarihine bakıldığında ise stoa felsefesinin Avrupa'nın farklı düşünsel dönüşümlerinde hiçbir yere sahip olmadığı kabul edilmiş olmalı ki bu konu sadece felsefe alanına bırakılmış, orada bile hak ettiği ilgiyi görmemiştir. Bu durumun bir diğer göstergesi ise antik çağdan ve bu çağın insanlığa bıraktığı mirastan bahsedilirken ülkemizde hep Platon ve Aristoteles'in isimlerini görüyor olmamızdır. Bu durumun ortaya çıkmasında kuşkusuz Batı düşünürlerinin dönemi dar bir çerçevede yorumlayagelmelerinin de etkisi yadsınamaz. Ne Antik Yunan ne de Antik Roma yalnızca Platon ve Aristoteles ile açıklanabilir; ne de Avrupa tarihi bu iki isim üzerine yapılmış olan tartışmalarla sınırlı kalmış gibi sunulabilir (Bouwsma, 1975: 3-5).

Aşağıda da tartışılacağı gibi, özellikle Rönesans ve Reformasyon dönemlerinden itibaren stoacı felsefenin dönemin olumsuzluklarına antik mirasın diğer birçok ögesinden daha iyi çözüm önerdiğine inanılmıştır. Çoğunlukla bu felsefeyle özdeşleştirilen isimlere atıfta bulunularak oluşturulan söylemler, hem düşünsel tartışmalara hem de daha somut siyasi ve düşünsel programlara yön vermiştir. Bu yazıda da esasen, yeni stoacıIık olarak tanımlanan düşünsel faaliyetin Yeni Çağ Avrupa tarihinde, sosyoekonomik, dinsel ve politik yıkımlar neticesinde ortaya çıkmaya başlayan merkezî devlet yönetimleri bünyesindeki yeri tartışılacaktır. Genel olarak bu merkezî yapılanmaların, bir antik çağ mirasının, o dönem merkezî oluşumlarının içerisinde ne kadar da önemli olduğunu göstermek amaçlanmaktadır.

Antik çağ düşüncesi ve Hristiyanlık, Batı toplumları için vazgeçilmez birer düşünsel kaynak oluşturmuştur. Bu iki başlığın dönüştürücü, düzenleyici ya da meşrulaştırıcı etkileri, yoğun olarak kriz anlarında görülmekle beraber, bugüne kadar yapılan Avrupa tarihi dönemselleştirmelerinin neredeyse hepsinde yadsınamaz bir yere sahip olmuştur. Aynı şekilde önemli olan diğer bir konu ise bu iki düşünsel faaliyetin aşağı yukarı on dokuzuncu yüzyılın ortalarına kadar genellikle toplumun herhangi bir kesiminde varlığından şüphelenilen yeniliği reddetme ya da düzensizlikleri defetme gibi işlevlere sahip olmalarıdır. Burada, genel olarak antik çağ düşüncesi ve daha özelde ise bugüne kadar çok da dikkat çekmemiş olan stoacı ve yeni stoacı söylemin Avrupa tarihindeki, Rönesans sonrası artan önemi üzerinde durulacaktır.

Aslında burada girişilen çaba Rönesans olarak tabir edilen dönemdeki düşünsel faaliyetin bir uzantısı olmakla beraber onunla karşılaştırıldığında oldukça mütevazı kalmaktadır. Gerçekten de bu dönemde birçok faktörün bir araya gelmesiyle antik dönem düşüncesine muazzam bir ilgi uyanmıştır. Eskilerin bıraktıkları eserlerin ilk elden incelenmesi sonucu, on altıncı yüzyılla birlikte o dönem yazarlarının farkında olmadıkları bir düşünsel zenginlik yaşandığını vurgulamak gerekir. 
Ancak bu noktada günümüz akademisyenleri, yazarları ve politikacıları tarafından dikkat edilmesi gereken çok önemli bir nokta vardır. Bu dönemde ortaya çıkan yorumsal zenginliğin mimarları, çoğu durumda yeni bir dünya arayışında olmamışlar; aksine yaşadıkları dönemdeki toplumsal, politik ve ekonomik çarpıklıklara eski dönemlerden miras aldıkları erdemlerle çare aramışlardır. Yani o dönem entelektüelleri için antik çağ her dönemde ortaya çıkan sorunları çözebilecek çeşitli düşünsel olanaklara sahiptir. Geçmiş ve eski, gelecek ve yeni olandan her zaman daha değerli olarak kabul edilmiştir. Eğer gerçekten bir yenilikten bahsedilecekse bu, yeni fikirlerin varlığında gerçekleşmemiştir. Tersine politik ve dinsel savaşlarla daha da karmaşıklaşan toplumsal sorunlara çare aramada geçmişin ve değerlerinin daha çok yol gösterici olduğu fark edilmiştir. Bu dönemlere hâkim olan düzensizliğe çözüm yollarından birisi de, bu yazının konusunu oluşturan stoacı felsefenin her alana uygulanabilecek olan nitelikleridir.

Stoacı felsefenin yeniden canlanışı ve yoğun bir ilgiyle araştırılması Yeni Çağ Avrupa tarihi açısından oldukça önemlidir. Bu ilgi on altıncı yüzyıldan itibaren hız kazanmış ancak tek bir gelişim çizgisi izlememiştir. Değişik ülkelerde birçok düşünür ve yazar tarafından somut sorunlara çözüm bulmak amacıyla stoacılığın farklı yönlerine vurgu yapılmış ve antik çağın farklı isimleri öne çıkarılmıştır. Ancak genel anlamda bu ilgiye ilham kaynağı olmuş birkaç temel isimden söz etmek mümkündür. Cicero, Tacitus, Seneca, Aurelius, Epictetus ve Boethius gibi isimler stoacı felsefenin en önemli simaları olarak ele alınmış ve onların yazdıkları eserler dikkatli bir şekilde incelenerek içerdikleri dersler yeniden üretilmiştir.

Batı literatüründe Yeni Çağ üzerine yapılan değerlendirmelerde yeni stoacılık olarak adlandırılan bu düşünsel faaliyetin o devir için oldukça önemli olduğunu görmek mümkündür. Peter Burke'e göre 1580-1700 yılları arasında en az yüz isim, Tacitus ve onun eserleri üzerine yorum yapmış ve bunlardan, önemli gördükleri noktaları alarak acil çözümler bekleyen sorunlara sistematik olarak uygulamışlardır (Burke, 1991: 479-498). Bunun sonucunda Tacitus bazen üslubuyla, bazen tarihçiliğiyle, kimi zaman ahlakçıığıyla ve kimi zaman da siyaset teorisindeki ustalığıyla yeni stoacı erdemlerin en göze çarpan kaynaklarından birisini temsil eder.

Bilindiği gibi, antik çağa ait bu eserlerin yoğun bir yeniden değerlendirmeyle sunulduğu dönem, sonuca ulaştırılamamış ciddi dinsel ve ideolojik konuların tartışılmasına tanıklık etmiştir. Bu açıdan bakıldığında, Quentin Skinner'e göre, bu çağda tartışılan siyaset teorilerinde dahi stoacı değerlerin gözardı edilemeyecek hâkimiyetinden söz etmek gerekmektedir (Skinner, 1977-8: xiv). Özellikle Kıta Avrupa'sı göz önüne alınırsa bu konu hakkında yapılan yorumlar daha da çarpıcı olacaktır. Günümüzde yeni stoacılığın modern devletlerin ortaya çıkışında oynadığı role ilişkin en çok tartışılan değerlendirmeyi Gerhard Oestreich yapmıştır. Ona göre yeni stoacı Rönesans yorumu, dönemin karmaşık sorunlarına çözüm bulabilmek için bu felsefenin daha çok status quo oluşturabilecek noktalarına vurgu yapmıştır. Özellikle Fransa'dan başlayarak daha 
merkezî siyasi oluşumların ortaya çıkmasında etkili olmuş ve buna uygun düşünsel altyapıyı hazırlamıştır. Oestreich (1982: 29-30)'a göre düzen, disiplin ve sükûnet üzerine yoğunlaşan yeni stoacı etki, Prusya devletinin ortaya çıkışında hâkim olan bir söylem yaratmıştır. Düşünsel boyutta ise stoacılığın gelecek kuşaklar için ortaya çıkardığı en büyük yeniliği Norman Davies Avrupa Tarihi isimli hacimli eserinde belirtmeden edememiştir. Davies'e göre stoacı düşünceler üzerine kurulmuş ve aşağıda detaylı bir şekilde anlatılacak olan Justus Lipsius'un metinlerinin Latinceden çevrilerek okunması 1670'lerden 1770'lere kadar geçen süre içerisindeki hararetli dönemin ideolojik temelini biçimlendirmiştir. Bu aşamada, bilimsel devrimin yanı sıra Descartes ile özdeşleştirilen rasyonel yöntemin de temel ilkeleri ortaya çıkmıştır (Davies, 2006: 643).

\section{Stoacılık Mirası}

Genel olarak stoa felsefesinin izini M.Ö. 300'lerde yaşamış Kıbrıslı Zenon'a kadar geri götürebilmek mümkündür. Ancak onun ve yine ilk dönem stoacılar olarak alınabilecek takipçilerinin öğretileri bizim burada inceleyeceğimiz dönemin öne çıkan stoacı fikirlerinden çoğunlukla uzaktır. Yani Zenon'un felsefesi Rönesans ve Reform dönemleriyle karşılaştırıldığında daha soyut tartışmaları ele almakta ve temelde fizik ve logos kavramlarıyla ilgilenmektedir. Kendisinden yüzyıllar sonraki stoacı temellendirmelerden daha çok Sokrates ve Platon'un felsefi yaklaşımlarına benzemektedir.

M.Ö. 2. yüzyıldan itibaren ise -yani orta dönem olarak tabir edilen zaman dilimindestoacı öğretinin daha soyut ve dönemin politik sorunlarıyla bire bir ilgilenmeyen ilk dönem stoacı öğretiye kıyasla, pratik çözümlü ahlaki konularla daha fazla meşgul olduğunu görüyoruz. Bu dönüşümle birlikte Helenistik dönem içerisinde stoacı düşünce sistemi dönemin toplumsal ve siyasi idaresinde görülen aksaklıklara daha fazla yönelmiş ve daha çok siyasi önem kazanmıştır. Sonuçta, aşağıda değinilecek olan Yeni Çağa ait bazı düşünürler stoacılığın pratikte uygulanabilir özelliklerini öne çıkararak ona daha ahlaki bir önem kazandırmışlardır.

Bu aşamada dikkate değer bir noktadan söz edilebilir. İlk dönemde pek fazla öne çıkarılmayan erdemli yaşama vurgusu, bu orta dönem stoa öğretisinde en önemli yeri teşkil etmeye başlamıştır. Buna göre, bir kişi felsefe yardımıyla kendisini eğitip geliştirmelidir. Böylelikle erdeme yaklaşmış bir vatandaş olarak etkin bir biçimde toplumsal alanların hepsinde kendine düşen görevi yapmalıdır. Bu, dış dünyanın çekiciliğine kapılıp erdemden uzaklaşılacağını, bu yüzden de insanın daima kendisine dönmesi ve toplumsal işlerden sıyrılması gerektiğini vurgulayan Epikürus felsefesine daha net bir tavır almayı getirmiştir. Ayrıca, Rönesans hümanizmi ve Reformasyon dönemi savaşları arasında bocalayan ve erdemli olmanın ne olduğunu sorgulayan eğitimli şahsiyetler için de gerekli tartışma alanını şekillendirmiştir. Bu yoruma göre, insan kamu yararını göz önünde bulundurarak eylemlerini metanet, değişmezlik ve akılcılık gibi temel ilkelere 
uyarak gerçekleştirmeli; buna paralel olarak da toplumda etkin görevler üstlenmelidir.

Roma İmparatorluğu'nun tarih sahnesindeki yerini alması ve Yunan şehir devletlerini de içine alarak genişlemesi sonucunda, stoa felsefesinin genel olarak kabul edilen dönemselleştirilmesinde son döneme de geçilir. Bu dönem içerisinde Romalı düşünürler bu eski felsefeyi benimsemişler ve daha sonraki dönemlere daha cazip gelen noktaları öne çıkarmışlardır. Artık bu dönemden sonraki stoacılık daha çok görev, zorunluluk, karar alma ve pratik ahlaki noktalarla ilgilenmiş, gelecek kuşakların stoacı erdemler olarak gördükleri alanları belirlemiştir (Allan, 2000: 4).

Cicero, Seneca ve Tacitus dönemlerinde stoacı vurgu fizik ve logos anlayışından daha çok neredeyse tamamen pratik toplumsal ve siyasi sorunlarla ilgilenen bir ahlak felsefesine doğru kaymıştır. Bu dönem, ayrıca stoacı erdemlerin metinler aracılığıyla günümüze ulaşmasında en önemli zaman dilimini kapsar. Bu aşamada, ilk ve orta dönem stoacıların düşünceleri farklı yazarlar tarafından ele alınmış, istenilen noktalarda değişikliklere gidilmiş ve bazı içeriklerinde ilk dönem stoacıların pek de kabul edemeyeceği düşünce biçimleri geliştirilmiştir. Aslında, günümüz araştırmacıları stoacılık hakkındaki bütün bilgilerini ve hatta sonraki dönemlere taşınmış bakış açılarını hep bu çağda yaşamış isimler aracılığıyla edinmişlerdir (Colish, 1990: 21). Bu durum temelde, sonraki yorumcuların bu Roma düşünürlerinin sahip oldukları bakış açılarını yeniden ürettikleri anlamına gelir.

Yukarıda değinilen farklı dönemlere rağmen genel bir stoacı yaklaşımın temel bazı özellikleri de belirli bir çerçeve dâhilinde hep korunmuştur. Bunlardan bahsetmek benzer ve farklı yönlerin iyi anlaşılmasına yardımcı olacaktır. Bunlar aslında, stoacı düşünüş biçiminin belirleyici ve temel noktalarıdır. Eğer farklı dönemlerdeki politik, dinsel ve toplumsal olayları dışarıda bırakırsak, genel hatlarıyla kabul edilen birtakım stoacı öğretilerden bahsetmek mümkündür. Bunlar değişik dönemlerde somut olaylarla şekillenen yaşam ve düşünüş biçimlerinde düşünürlerin çıkış noktalarında değişmez olarak kalan ya da genellikle çok temelden sarsılmayarak pratik sonuçlar doğuran anlayışlardır. Buna göre herhangi bir dönemde stoacı etkiden söz edildiğinde ilk olarak doğal aklın ahlaki boyutundan söz etmek gereklidir. Bu da Epiküristler ve septikler gibi daha şüpheci düşünürlerin aksine sosyal yaşamda erdemli olmayı, doğal aklın getirdiği etkinlikle de hayatın her alanına katılımı sağlamayı amaçlar. Örneğin, Roma dünyasında akıl üzerine yapılan pratik vurgu neticesinde Aristoteles ve Platon'un Yunan şehir devletleri evrensel ve geniş bir alana yayılmış, siyasal toplumun taleplerini karşılama noktasında rasyonel açıdan yetersiz görülmüş, bunun yerine Roma'nın kozmopoliten iddialarıyla uyumlu olabilecek bir biçimde, Zenon'nun evrensel dünya görüşü değer kazanmıştır.

Bunun pratik yansıması çift yönlü olmuştur. Bir yanda, genişleyen Roma İmparatorluğu'na evrensel ve yayılmacı bir ideolojik meşruiyet sağlanmıştır. Diğer 
taraftan ise kriz ve yıkım anlarında ortaya çıkan yönetim boşluğu ya da otoriterliği gibi zıt uçları temsil ettiğine ve sonuçta da bu yönetim biçimlerinin erdemli yaşantıyı engellediğine inanılan anlarda, bu istenmeyen sonuçlardan kaçıp teselli bulmanın yolu açılmıştır. Her iki durumda da hâkim olan görüşe göre, insanoğlu her koşul altında politik birimlerden bağımsız olarak yaratılıştan gelen evrensel aklın denetimi altındadır ve siyasi yöneticilerden ziyade logosa bağlıdır. Bunun neticesinde, özellikle Roma döneminde vatanseverlik ve sosyal alana etkin katılım gibi temel ahlaki öğretiler geçerliliğini korurken vurgu daha çok evrensel olarak logos tarafından ahenkli bir sistem içerisindeki dünya vatandaşlığı anlayışına kaymıştır. Yani temel olarak Epiküristler ve Kiniklerin çok daha kişisel olan, insanın iç dünyasını eğitmeyi savunan anlayışları daha kozmopolit ve çok kültürlü bir toplum olan Roma İmparatorluğu için yetersiz ve hatalı görülmüş; bunun yerine kişinin kendisinden ziyade kamu yararını ön plana alan ve insanlığa hizmeti vurgulayan stoacı anlayış gelişmiştir (Chew, 1988: 8-9). Stoacı düşünceden çıkan, insanın kendi içine dönmesi gerekliliği ile evrensel yurttaşlık temelinde gelişen politik tahayyül arasındaki gerilim, Romalı düşünürlerin teorik ve pratik tutumlarını belirlemiştir. Sheldon Wolin'in belirttiği gibi, "Roma'nın kendi içsel çekişmelerinin toplumu yormaya başladığı ve emperyal genişlemenin devletin şişmesine" neden olduğu zorlayıcı durumlarda, yani bir nevi siyasal toplumun "temel" dinamiğini kaybetme tehlikesiyle karşı karşıya kaldığı anlarda, stoacılık kendine has değer vurgusuyla onarıcı ya da tamamlayıcı bir rol üstlenmiştir. "Felsefe ve toplum arasındaki gerilim" noktası, her ikisi de "apolitik" olduğu sürece ortadan kalkabilir (Wolin, 2004: 74-75).

Farklı dönemlerdeki sosyal ve politik gelişmeler dikkate alındığında durum daha karmaşık bir hâl alır. Stoacılığı savunan seçkin şahsiyetlerin Roma siyasi hayatında etkin biçimde yer almış olmalarından kaynaklanan ve gelecek toplumlara farklı tecrübeler miras bırakacak olan bir durumdur bu. Örneğin, Cicero kendinden önce kusursuz işlemiş ancak kendi çağında zayıflamaya başlayan cumhuriyetçi anlayışın iyimser bir savunucusu olmuş; Seneca görev bilincine sahip biri olarak karamsarlık ve kargaşa içerisinde dahi Nero'ya ve onun yardımcılarına stoacı ahlakı yansıtan tavsiyeler vermiştir. Tacitus ise Roma tarihinde meydana gelen değişiklikleri analiz ettiği, felaketlerin kaçınılmazlığını savunduğu tarih kitabındaki bakış açısını, o dönemde Britanya yöneticisi olan Agricola'nın üvey kardeşi olarak ve politik işlerde etkin bir yer edinerek benimsemiştir.

Daha somut başka bir örnek ise bizzat Roma İmparatoru olan Marcus Aurelius Antoninus'un stoacı erdemlere sahip filozof kral olarak tarihe geçmiş olması ve on sekizinci yüzyılın ünlü klasik çağ tarihçisi Gibbon'nın da onu Zenon'un örnek yöneticisi olarak tanımlamış olmasıdır. Ancak iyimser ve etkin bir stoacı yaşam anlayışı Roma İmparatorluğu'nun sonlarına doğru artan sorunlarla gelişerek ve karamsarlaşarak Epikürcülerin iç dünya vurgusunu içerisine almaya başlamıştır. Sonraki dönemlere aktarılan stoacı yorumların diğer önemli iki temsilcisi olan Epictetus ve Boethius bu durumu oldukça iyi yansıtmaktadırlar. 
Epictetus yaşamının büyük bölümünü köle olarak geçirmiş ve özgürlüğe kavuştuktan sonra erdemi dış dünyadan ziyade insanın aklın kontrolü altında olan iç dünyasına göre yorumlamış önemli bir isimdir. Boethius ise Roma'nın son yıllarında etkin devlet görevinde bulunduktan sonra Gotların ünlü kralı Teodoric'e hizmet etmiş başka bir stoacı düşünürdür. Onun elinde akıl, insanı sosyal yaşantıya yönlendirerek erdemi bulmasına bir vesile olmaktan ziyade dış dünyadaki olumsuzluklara göğüs gerip kötü talihi yenmenin ve iç dünyada huzura kavuşarak mutsuz olmayı önlemenin vazgeçilmez bir vasıtası hâline gelmiştir.

Sonuç olarak denilebilir ki Roma deneyimi içerisinde stoacı düşünüş giderek karmaşık bir hâl almış ve içerisinde hem Cicero ve Aurelius'un aktif bir yaşamı savunan iyimser yorumunu hem de Tacitus, Seneca, Epictetus ve Boethius'un kriz anlarında ele alıp olumsuzluklardan kaçmanın yollarını ve tesellisini oluşturdukları daha karamsar bir anlayışı barındırmaya başlamıştır. Bu iki yorum temel itibariyle gelecek dönemlerin anlayışlarına miras olarak kalmış ve çoğu durumda onlara meşruiyet kazandıran bir düşünce sistemine dönüşmüştür. Stoacı erdemlerin gelecek yüzyıllara aktarılmasında iki etkenden bahsetmek gerekmektedir. Bunlardan birincisi, burada özetlenen düşünüş biçimlerini içeren metinlerin her dönemde karşılaşılan sorunlara uygulanabilecek pratik öğretiler içermiş olmasıdır. İkinci ise stoacı erdemlerin özellikle orta çağlarda Hristiyanlıkla olan ilişkisidir (Allan, 2000: 7). Stoacıların erdem vurgusu, kamu hayatına faydalı olma yollarını aramaları ve ahlaklı yaşamanın üstünlüğü üzerine düşünceleri Hristiyanlığın temel öğretilerine yakın görülmüştür.

Hristiyanlığın teolojik yorumlarının felsefi ögelere açık olması neticesinde stoacılığın pek çok özelliği ona eklemlenebilmiştir. Aslında stoacılığın Hristiyanlıkla olan ilişkisi karmaşık bir meseledir. Stoacı düşüncenin Hristiyan teolojisinin temel bazı varsayımlarıyla çeliştiği noktalarda stoacılığa şüpheli bir yaklaşımı olduğu söylenebilir. Mesela Paul Tillich'in vurguladığı gibi, stoacı düşüncenin cesaret gibi kimi vurguları, Marcus Aurelius gibi etkili stoacı düşünürler tarafından dillendirildiğinde Hristiyan düşüncesine "alternatif" olabileceği endişesiyle "ciddi bir tehlike" olarak algılanmıştır (Tillich, 1959: 10-11). Fakat her ne kadar belli dönemlerde stoacı akıl vurgusu ile Hristiyanların kalp aracılığıyla geldiğine inandıkları lütuf ve inanç anlayışı zıt kutupları temsil eder gibi yorumlansa da, ikisinin bir arada bulunabileceği Rönesans ve Reform dönemi yazarlarınca savunulmuştur. Özellikle on altıncı ve on yedinci yüzyıllarda stoacı düşüncenin temel olarak duyguların dizginlenmesi, pagan fikirler ve akılcılıkla özdeşleştirilerek genel bir Hristiyanlık çerçevesi içerisinde tartışıldığı vurgulanmıştır (Chew, 1950: 1130-1145). Bu da stoacılığın farklı bağlamlarda farklı anlamlarla ortaya çıkmış olduğunu göstermektedir. Hristiyan din adamlarının bu temel ayrılığın farkında olup stoacılığı barbarların bir felsefesi olarak kaderine terk etme eğiliminde oldukları dönemlerde dahi stoacı felsefenin doğal denge ve düzen, aşkın bir güç tarafından yönetilen olaylar, mantıksallık, günahkâr ve düzensiz sosyopolitik yapının varlığı gibi düşünceleri her durumda Hristiyanlık içerisinde önemli bir yere sahip olmuştur. 


\section{Yeni Çağda Stoacılık Algısı}

Yeni stoacılığın Yeni Çağ Avrupa tarihi açısından en somut denilebilecek anlamı klasik tartışmalarda ortaya çıkmıştır. Bilindiği gibi, bu dönemi tarif ederken daha merkezî yapılanmaların yani mutlak monarşilerin ortaya çıkış sürecini anlatmak artık âdetten olmuştur. Bu tartışma bağlamında yeni stoacı öğretilerin önemi yine bu sürece ilişkin olarak anlatılabilir. Bu merkeziyetçi yapıların ortaya çıkmasında sosyoekonomik dönüşümlerin mi, yoksa dinsel ve politik ideolojik değişimlerin mi büyük önemi haiz oldukları yumurta-tavuk hikâyesini çağrıştıran tartışmaların ortaya çıkmasına neden olmuştur. Doğal olarak, bunların hepsinin tartışmasız fonksiyonları olmuştur. Merkezî yapılanmaların varlığı bağlamında yeni stoacılığın bariz öneminden bahseden Gerhard Oestreich'a göre Lipsius'un başını çektiği yeni stoacılar, etkilerini Prusya devletinde gösteren bir disiplin anlayışı yaratmışlardır. Genellemelerin pek rağbet görmediği günümüz tarihçiliğinde tabi ki bu tez genelgeçer bir kabul görmemiş; onun yerine konunun ihtiyatı bir şekilde ele alınması tavsiye edilmiştir. Bu konunun İngiltere, Fransa, Almanya, Hollanda, İskoçya ve İspanya'da ne tür etkiler yarattığı, konularında uzmanlaşmış tarihçiler tarafından tartışılmaktadır. Ancak her ne kadar farklı yorumlara ulaşılmış olsa da bu yazıda bütün etkilerden bahsetmek mümkün olmadığından bazı genellemelere gitmek kaçınılmaz görülmektedir.

Rönesans'ın antik çağa olan ilgisi artık herkesçe malumdur. Ancak on altıncı yüzyıla gelindiğinde ve Hristiyanlık teolojisine Roma İmparatorluğu'nun yıkılmasından sonraki en köklü eleştirinin Reformasyon olarak adlandırılan dinsel hareketlerle gelmesi sonucunda, antik çağ eserlerine olan ilgi çeşitlilik göstermeye başlamıştır. Politik ve dinsel ortamın gerilmesi ve tartışmaların alevlenmesi neticesinde daha pratik politik ve toplumsal düzenlemelere atıfta bulunan metinler hızla basılmıştır. Bu ise belirli siyasi ve dinî tavır alışlara daha kesin olarak meşruiyet kazandırma girişiminin bir uzantısıdır. Seneca'nın Epistulae Morales isimli eseri daha 1475 yılında yani Erasmus'un onu ele almasından oldukça önce tekrar basılmış, Cicero'nun De Officiis isimli yapıtı Avrupa'da o dönemde en çok okunanların başında yer almış, Epictetus'un Enchiridion'u ve Tacitus'un Annals'ı da pratik çözümler öneren kitaplar arasına girmiştir. Bunlara olan ilginin sadece daha seküler denebilecek bir düşünür grubunun ilgisi dâhilinde olmadığının en güzel göstergesi ise Calvin'in Seneca'nın De Clementia adlı eserini detaylıca yorumlamış olmasıdır.

Yeni Çağ Avrupa tarihi açısından burada bahsedilen antik çağ ve metinlerine olan ilgi aslında daha geniş dönüşümlerin izlerini taşımaktadır. Yeni stoacılık bağlamında ele alındığında, bu dönemin iki temel özelliği ortaya çıkar. Bunlardan birincisi, az önce de değinildiği gibi Aristoteles ve Platon'un daha metafizik ve soyut anlatılarından, stoacılık gibi daha pratik amaçlara hizmet edebilecek metinlere yönelik artan ilgidir. İkinci olarak ise bu yeni stoacı tartışmaların içerisinde meydana gelen yorumsal farklılaşmadır. Yani bu felsefeden en doğru ve faydalı bilgiyi "Hangi yazarlar hangi konular bağ- 
lamında ele almıştır?" sorusunun doğurduğu seçmeci yapının ortaya çıkışı. Bu açıdan bakıldığında seçilen yazarlardan, o dönem meydana gelen olayların ne gibi pratik ihtiyaçlar doğurduğunu gözlemlemek daha kolay olmaktadır. Daha somut olarak belirtmek gerekirse Rönesans'ın ilk dönemlerinde Cicero'nun daha ağdalı ve söyleme dayaIı üslubuna olan ilginin Reform hareketlerinin ve diğer siyasi olayların tarih sahnesindeki yerlerini almaya başlamasıyla yerini, Seneca ve Tacitus'ta hâkim olan daha kısa ve net üsluba bırakmış olmasıdır (Salmon, 1980: 307-333). Bu noktada, düşünüş biçiminde ortaya çıkan ve dönemin siyasetini yönlendiren bir farklılaşmadan söz etmek mümkündür. Yani, her ne kadar şikâyet edilen yıkıcı olayların çözümü antik çağ mirasında aransa da, bu mirasın farklı yorumlanması ve çeşitliliği bir anlamda dönüştürücü etki yaratmıştır.

Bilindiği gibi, Rönesans'ın temel özelliği, antik çağda tartışarak ikna etme kabiliyetini göstermiş Cicero gibi iyi bir retorik ustasının metinlerinin ilgi çekmeye başlamasında yatmaktadır. Üslup üzerinden yürütülen tartışmalar, Hristiyanlığın daha evrensel bir boyutunu öne çıkarmaya çalışan düşünürler için gayet etkili bir metod sunmuştur. Dinleyicileri ikna etmenin en güzel yolu, Cicero gibi dili iyimser bir bakış açışıyla etkili kullanarak argümanları sunmaktır. Fakat acil çözüm bekleyen görünürdeki sorunlar için Cicero'nun bu iyimser ve ağdalı üslubu pek yarar sağlamamaya başlayınca, Machiavelli ve Erasmus'un isimleri daha çok Seneca'ya, onun stoacı akılcılığına ve daha sade üsluplara yaptıkları vurguyla ön plana çıkmıştır. Cicero'yu daha çok ikinci plana iten bu tavır, Fransa ve Hollanda gibi dinî ve politik savaşlarla yıkıma uğramış ülkelerde bulunan yazarlarda ve özellikle Lipsius'ta etkisini gözle görülür bir biçimde göstermiştir (McCrea, 1997: 11-16).

\section{Justus Lipsius ve Yeni Arayışlar}

Burada bahsedilecek en önemli isim, Erasmus'un çağdaşı olan ve yeni stoacı akımın sistematik temsilcisi olarak kabul edilen Justus Lipsius'tur. Dönemin, Türkiye'de pek tanınmayan, en önemli isimlerinden olan Lipsius, Hristiyanlığın birleştiricilikten ziyade bölünmelerin nedeni hâline gelmesiyle harekete geçen bir düşünürdür. Çareyi ise hümanist yazarlığın temel prensiplerini gözden geçirmekte ve Tacitus ile Seneca'nın savundukları görüşleri birleştirerek stoacı öğretilerin yeni bir yorumunu sunmakta arar. Lipsius, Kıta Avrupa'sının en karışık olduğu dönemlerden birinde yaşamış ve bu ortama göre oluşturduğu politik bakış açısını yeni stoacı öğretilerle donatmıştır. 1547'de Brabant'ta doğmuş, Köln'de Cizvit Kolejinde öğrenci olmuş, II. Felipe döneminde görev alan Kardinal Granvelle'e Latince sekreterliği yapıp yavaş yavaş yükselmeye başlamıştır. Luther'e yakın Jena Üniversitesinde daha sonra da Calvin'e yakın Leiden Üniversitesinde profesör olmuş ve ilginç bir şekilde tekrar Katolik eğitim veren Louvain'de eğitmenlik yapıp, bu süre zarfında da çeşitli siyasi olaylara tanıklık etmiş 
birisidir. Onun stoacı felsefeye olan ilgisini sadece Avrupa'daki dinî ayrışmalar şekillendirmemiş; özellikle Hollanda'nın İspanya'ya karşı yürüttüğü bağımsızlık mücadeleleri de siyasi anlamda ona esin kaynağı olmuştur (Voogt, 1997: 1231-1249). Bütün bu karışıkııların onun üzerinde bıraktığı en büyük tesir, anlayışının temelini oluşturan düzen ve güvenlik konularını ön plana çıkarmasında görülebilir. Bu bakımdan, klasik stoacı metinler onun gözünde vazgeçilmez bir yere sahip olmuş ve çağdaşlarınca da kriz anlarına uygulanabilecek en etkili askerî önlemleri ortaya çıkaran bir düşünür olarak anılmıştır. Döneme esin kaynağı olması yanında aslında en büyük özelliği temel iki stoacı metni; yani Tacitus'un Annals ve Histories'ini, Opera Omnia Philosophi Senecae başı̆ğıla da Seneca'nın yazılarını derlemesidir.

Lipsius'un bütün kaygısı aslında daha önce de vurgulanan temel iki stoacı öğreti arasındaki kararsız tutumunda görülebilir. Yani, bu kadar düzensizliğin ve çatışmanın olduğu bir ortamda insan erdeme siyasi ve toplumsal yaşama aktif bir şekilde katılarak mı, yoksa iç dünyasına dönerek ve bu dış çekişmelerden kendisini olabildiğince soyutlayarak mı ulaşabilirdi? Lipsius'a göre insanlar genel olarak Seneca'da daha çok gözlenen çürüme ve çekişmelerin varlığını kabul ederek melankolik bir tarzda kamusal alana ahlak anlayışının bir getirisi olarak katılmalı ve erdemli olmayı öğrenmelidirler. Bu bakımdan, savaş taktiklerini de içeren bir dizi pratik yönetimsel ve davranışsal yaklaşımı en iyi sergilediğine inandığı Tacitus'un eserlerine başvurmuştur. Bunun sonucunda, etkili bir devlet yönetimi vurgusunu öne çıkarmış ve bazen oldukça merkezî ve mutlakiyetçi denilebilecek bir yönetim biçiminin yayıcısı hâline gelmiştir. Böylelikle Tacitus üzerinden yürüttüğü tartışmalarıyla hikmet-i hükümet (raison d'être) olarak tanımlanan anlayışın Machiavelli ile birlikte en önde gelen temsilcilerinden olmuştur. Aslında, bu pratik siyasi tavır alışın yeni stoacılık ile olan ilişkisi bu antik çağ felsefesinin metanet, dayanıklılık, akılıılık ve ihtiyat kavramlarına olan vurgusunda ortaya çıkmaktadır. Bu öğretiler dönem için oldukça iyi işleyebilecek bir pratiklik sağlar.

Lipsius aslında bütün öğretilerini daha sonraki dönemler için de vazgeçilemeyecek kaynak olan iki temel kitabında anlatmaya çalışmıştır. 1584 yılında yayımlanan De Constancia ve 1589 yılında yayınlanan Politica isimli eserleri bir yandan zor koşullar altında yaşayan insanları erdeme yöneltmenin yollarını aramış, öte yandan yöneticiler için acil çözüm yollarını göstermeye çalışan pratik öğretiler sergilemiştir. Aslında Lipsius'un temel uğraşı çağdaş ahlaki yargıları Seneca ve Tacitus'un üstün anlatımlarıyla sunduğuna inandığı antik çağ düşüncesiyle dönüştürmektir. Bu bakımdan zor bir görevi vardır; çünkü hem bu metinleri ve öğretilerini günün şartlarına uyarlayarak çıkış yolu olarak sunmak zorundadır; hem de bu klasik çağ anlayışlarını Hristiyanlıkla çatışmayacak şekilde benimsetmekle görevlidir. Aslında, bu iki eserinde bu zor görevin üstesinden gelmiş gibi görünüyor.

De Constantia'da yeni olan tek şey yorumdur; yani bir yandan Seneca'da bulunan stoacı erdem çözümlenir, öte yandan Hristiyanlığın temel öğretilerinden alınan sadakat 
ve istikrar anlayışı stoacılığa titizlikle eklemlenir. Lipsius'un bu kitabında asıl yapmaya çalıştığı şey, Seneca'nın felsefesi aracılığıyla kendisinin ve çağdaşlarının tecrübe ettikleri dinî ve siyasi felaketlere katlanabilmenin yollarını aramak ve onları çözüme kavuşturabilmektir (Allan, 2000: 17). Buna uygun temel çerçeveyi, dünyada olan her şeyin Tanrı́nın isteğiyle ve kaderin değiştirilemezliğiyle meydana geldiğini söyleyerek oluşturmuştur. Bu bağlamda, dünyada olan hiçbir şey tesadüfi ve amaçsız değildir. Bunu söylerken hiçbir zaman gücün, zalim yöneticilerin ve tarihsel gerçeklerin yönlendirici etkisini göz ardı etmemiştir. Bunların varlığını kabul ederken yine temel olarak aslında bu gerçeklerin Tanrı́nın dünyanın gidişatını garanti altına aldığı olaylar silsilesi olarak yorumlamıştır. Bu genel anlatı içerisinde vurgulamak istediği çok önemli bir nokta vardır. Bu da ortaya çıkan olumsuz koşulların aslında o döneme has olmadığını, tarihin her anında böylesi felaketlerin yaşandığını kanıtlamaktır. Eğer bu değişmezlik gözler önüne serilirse bu şartların düzene kavuşturulması daha da kolaylaşacaktır. Bu noktada stoacı akıl vurgusu öne çıkar. Yani bu şartlar altında güven duyulacak en iyi yol aklın stoacı yol göstericiliğine sarılmaktır (Lipsius, 1594: 10-11). Akıl insanlara çatışmalara sebep olan duyguların dizginlenip kontrol altına alınmasını öğretmektedir. Aslında bu nokta bütün dönemler boyunca stoacılığa yakın duran düşünürlerce temel olarak vurgulanan şeydir (Brun, 1997: 96-103).

Eğer bir insan erdemli olarak hem dış dünyanın yıkıcılığından kurtulmak istiyor hem de bu şartları istikrara kavuşturmak peşinde koşuyorsa evrensel akılla uyumlu olmalı ve duygularını kontrol etmelidir. Bunun sonucunda olayları daha açık bir erdemle yorumlar ve bu olayların her dönemde olduğu ön kabulüyle yola çıkarak doğa yasasının ve onun yaratıcısı Tanrı'nın kurallarını bularak hem teselliye hem de mutluluğa kavuşur. Bütün toplumsal oluşumları da buna göre düzenleyerek istikrarı sağlar. Bu düzensizliği ortaya çıkarıp etraftaki savaşların temel sebebi olan şey üç zehirli duygusal yaklaşımı dizginleyememekten kaynaklanır. Bunlar hilekârlık, başkalarına aşırı acıma ve vatanseverliktir. Bütün olumsuzlukların sebebi bunların akıl liderliğinde yönlendirilememesidir. (Lipsius, 1594: 18) Eğer insan, zararlı duygulardan arınıp vatanseverlik gibi olumlu kavramları da rasyonel bir çerçevede yeniden tanımlamayı başarabilirse istikrara ve düzene kavuşmak mümkün olacaktır. Ancak, bunu toplumsal etkinlikten uzaklaşarak ve bir nevi çileciliğe bürünerek yapmak hata olacaktır. Stoacılar ve Hristiyanlar genel olarak evrensel boyutta düşünmeli ve erdemli bireyler olarak cennette yerlerini almalıdırlar. Bu bakımdan Lipsius'un duyguları bir kenara bırakıp bütün dinsel ve politik olaylara tarafsız yaklaşma önerisi, stoacı kaderciliği Hristiyan kaderciliğine ekleyerek karmaşayı ortadan kaldırmanın ön koşulu olmuştur.

Aslında pratik getirileri bakımından düşünüldüğünde Lipsius'un Politica'sı daha önemlidir, çünkü doğrudan yöneticilere hitap eder ve yukarıda değinilen öğretileri onlar için daha çekici hâle getirir. Dolasıyla toplumsal dönüşümün önü açılır. Yani eğer politikacılar stoacı anlayışı benimserlerse toplumdaki kargaşa ortadan kalkar ve hem siyasi hem 
de dinî bir status quo yaratılabilir. Bu düşüncenin şekillenmesinde Lipsius, Tacitus'a çok şey borçlu olduğunu düşünmektedir. Daha önce de belirtildiği gibi, bu dönemde Cicero ve Seneca-Tacitus arasında hangisinin vurgulanması gerektiğine dair bir tartışma zaten mevcuttur. Lipsius bu tartışmada birbirleri arasında kesin çizgiler oluşturmasa da Tacitus ve Seneca'dan daha fazla yararlanmış görünmektedir. Politica'sını da Tacitus'un tarihinden çıkarılabilecek sonuçlar üzerine kurmuştur. Bu eser, temel olarak kamusal çıkarı ihtiyatlı bir şekilde ön plana almayı vurgulayan ve devlet idaresi için pratik öğretiyi var eden bir yaklaşımla yazılmıştır. Bu konunun biraz daha açıklığa kavuşturulabilmesi için öncelikle daha önceki dönemlerde şekillenen birkaç özellikten bahsetmek aydınlatıcı olabilir.

Rönesans'ın antik çağ metinlerine olan ilgisi yeni gelişmeleri beraberinde getirmiştir. Bu dönemi Batı tarihçileri, Roma örneği ekseninde çağdaş toplumsal kargaşanın çözüme kavuşturulması isteği ve süreci olarak tarif ederler. Tabi bu anlayış, beraberinde önemli sonuçlar doğuracak bir kararsızığı da getirir. Roma dönemi tecrübeleri tamamen taklit edilip kendisinden yüzyıllarca sonraki bir döneme aynen uygulanabilir mi, yoksa bu mümkün değil midir? Bazıları bunun mümkün olabileceğini savunurken bazıları ise daha sonradan ilerleme fikrinin alt yapısını oluşturacak başka bir görüşe yani tarihselciliğe vurgu yapmışlardır. Buna göre o çağın anlayışı ve kullanılan iletişim dili kendi bağlamına özgüdür ve aradan geçen zaman başka anlayışların doğmasına yol açmış, sonuçta da iki kültür arasında farklılıklar doğmuştur; bu yüzden Roma çağı hiçbir şekilde on altıncı yüzyılda canlandırılamaz.

Lipsius ise bu iki zıt kutbun arasında bir görüşe daha yakın olmuştur. Lipsius'a göre çıkarılması gereken dersler hep antik çağ mirasında aranmalıdır. İşin özü eski metinlerin orijinallerinden okunmasında yatar. Ancak Lipsius'un Politica'sındaki vurgu, Tacitus'un her şeyin geçici bir karaktere sahip olmasını göstermekteki başarısı üzerinedir. Yani Tacitus'un kaydettiği her şey aslında on altıncı yüzyıl insanının yaşadığı felaketlerin her çağda yaşanmış olduğunu gösterir. Bu hayati bir derstir ve kişi bu dersleri antik çağ mirasından, Tacitus'un ve Seneca'nın metinlerinden süzüp çıkarmalı, sonrasında da eylemlerini ona göre düzenlemelidir.

İşte Lipsius bu temel noktayı vurguladıktan sonra Politica'da yöneticilere yapılması gerekenleri göstermeye çalışır. Eğer her dönem böyle yıkıcı olaylara şahit olduysa yapılması gereken de yine eski uygulamalardan düzeni sağlayıcı olanlara sadık kalmaktır. Bu bağlamda, Lipsius'un bazı tarihçilerce çokça vurgulanmış merkezî ve otoriter yönetim anlayışına geçilir. Lipsius her ülkenin mevcut sınırları içerisinde sadece bir dine ve politik örgütlenmeye izin vermesi gerektiğini savunur. Ülkeyi yöneten her kimse toplumdaki farklılıkları göz ardı ederek tek bir ideolojinin koruyucusu olmaIıdır ve çoklu sesleri gerekirse şiddet kullanarak bastırmalıdır (Lipsius, 2004: 387-391). Bu yaptırımların yeri, zamanı ve yöntemi yöneticilere kaldığı için bunun getirisinin bir bakıma hikmet-i hükümet anlayışı olduğu söylenebilir. 
Aslında Lipsius bu yargılarına ulaşırken yine antik çağ öğretilerinden yararlanmıştır. Bunlardan birinin değişmezlik ve sadakat anlamına gelen "constancy" olduğunu söylemiştik. Bu eserinde, belirli koşullar altında ne yapılacağının kararını verme bilgeliğine sahip kişinin erdemini vurgulamada kullanılan "prudence" (öngörü, tedbir) kavramından yararlanmıştır. Böylesi bir vurgu aslında raison d'être (hikmet-i hükümet) anlayışını savunan yazarlarda çokça rastlanan bir özelliktir. Bu kavram beraberinde genellemelerden özel durumların incelenmesine doğru bir anlayışı yerleştirir. Lipsius bu bilgeliğe iki ögenin kullanılmasıyla erişilebileceğini düşünmüştür. Bunlar geçmişin mirası ile bu mirasın güncel, pratik ve etkin kullanımıdır. Bunlardan birincisine tarih hizmet ederken diğerine her koşul altında bu tarihsel mirası uygulayabilme gücü eşlik etmiştir. İşte bu noktada, devlet idaresini bir sanat olarak gören Machiavelli ve Bodin gibi yazarlardan ayrılmış, bu sanatın kullanılabilmesi için tarihsel, bir nevi de metinsel hazinenin ön koşul olduğunu vurgulamak istemiştir (McCrea, 1997: 18). Şüphesiz, Machiavelli gibi yazarlar için de tarihî ve metinsel hazine büyük öneme haizdir. Fakat Lipsius için tarih, örnek alınması gereken ahlaki derslerin çıkarılacağı mutlak ve kadim bilgelik kaynağıdır. Lipsius'un mutlak otoriteyi savunan bu yazarlardan ayrıldığı bir başka nokta ise ideal yöneticinin elinden otoriteyi fütursuzca kullanabilme hakkını almış olmasıdır. Bu anlayışa göre zalim olduğu düşünülen bir yöneticiyi isyan ve başıbozuklukla tehdit etmemenin yollarını bulmak temel olarak kralın kendisinden geçer. Yani kral her türlü yola başvurma yetkisine sahip olmak yerine ideal stoacı kral olmayı ve tebaasını bir arada tutmayı öğrenmelidir. Bir nevi idareci, tarih ve stoacı öğretiyle sınırlıdır. Lipsius bunu yaparken Cicero'nun tarihin önemini vurguladığı yerleri almış ancak onun tartışmayı ön plana alan ve ağdalı üslubunu terk etmiştir. Diğer yandan ise Seneca ve Tacitus'un tarihi gösterme ve yorumlama yöntemlerini, yine onların erdemli bir yaşantının gerçeklerini göstermedeki faziletleri nedeniyle öne çıkarmıştır. Lipsius'un bu temel iki eseri aslında günümüz tarihçilerine Yeni Çağda görülmeye başlayan merkezî yapılanmaların çok geniş bir yelpazede çok farklı kişilerce tartışma konusu edildiğini gösterir. Antik çağ ve metinleri, yıkıcı politik ve dinî savaşların her kesimden insanı yıprattığı bir dönemde çözüm üretmesi bakımından eşsiz bir araç olarak devreye sokulmuşlardır.

Yukarıda açıklanmaya çalışıldığı kadarıyla on beşinci ve on altıncı yüzyıllarda etkisi çok sonraki dönemlerde dahi görülecek bir tartışma yaşanmıştır. Özellikle Reformasyonun getirdiği yıkıcı ve dönüştürücü dinsel savaşların yaşandığı bir çağda, düzeni geri getirmesi umuduyla ve dört elle antik çağ düşüncesine başvurulmuştur. Erasmus'tan Calvin'e, Machiavelli'den Montaigne, Muret ve Bodin'e, Du Vair'den burada ele aldığımız Justus Lipsius'a pek çok düşünür bu antik çağ mirasını klasik Aristoteles ve Platon vurgusundan daha ötelere Tacitus, Seneca, Cicero, Boethius, Livy ve Epictetus gibi stoacı düşüncelerle özdeşleştirilmiş ve daha pratik çözüm önerileri sunmuş düşünürlere taşımışlardır. Bunun neticesi her ne kadar tüm detaylarıyla burada anlatılamasa da ger- 
çekten düşünce ve uygulama tarzları üzerinde oldukça etkili olmuştur. Özellikle Justus Lipsius'un sadakat ve istikrar ile öngörü veya sağgörü (prudence) gibi sıkça sözünü ettiği erdemler, hem çağdaşları hem de sonraki dönem düşünürler tarafından tekrar tekrar tartışılmış; ayrıca pratik anlamda dönemin politikalarına uygulanmıştır.

Elbetteki Lipsius'un giderek doğruluğuna inandığı ve eserlerinde sonuna kadar savunduğu otoriter ve merkezî hükûmet anlayışının yankıları her yerde eşit olmamıştır. Ancak örneğin Fransa, yoğun din savaşları sonucu 1572 yılında tecrübe ettiği Aziz Bartholomew Günü ve 1588-89 yıllarında III. Henri'nin öldürülmesiyle sonuçlanan taht kavgaları sonucunda Lipsius'un bir devlette bir din anlayışına daha çok yaklaşmıştır. IV. Henri'nin Lipsius'a devamlı surette davette bulunması ve onun eserlerinin geniş halk kitleleri arasında yaygınlaşması ve devletçiliğe giderek daha çok vurgu yapılması bu durumun somut göstergesidir (McCrea, 1997: 26). Yine Guillaume du Vair ve Pierre Charron gibi önemli düşünürler, Lipsius'un antik çağdan on altıncı yüzyıl dünyasına kazandırdığı yeni stoacı öğretiler sonucunda, hem daha milliyetçi ya da vatansever ögelere vurgu yapmışlar hem de devlet idare etme sanatı üzerine daha fazla öğütler vermeye başlamışlardır.

Dönemin Osmanlı İmparatorluğu ile birlikte en güçlü devleti kabul edilen Habsburg İmparatorluğu'nda da Lipsius'un fikirleri devlet idaresi için vazgeçilmez faydalar sağlamıştır. Reconquista ile başlayan ve karşı Reformasyon ile engizisyon uygulamasında devam eden bir süreçte bilindiği gibi İspanya devlet idaresinde politika ve din tamamen iç içe geçmiş durumdaydı. Lipsius'un tarih, hikmet-i hükümet ve askerî disiplin üzerine oluşturduğu tezi İspanya için oldukça büyük bir önem kazandı ve hem II. Felipe hem de III. Felipe zamanında Montano ve Figueroa gibi hümanist devlet idarecileri aracılığıyla kabul gördü (Corbett, 1975: 139-152). Lipsius'un klasik stoacı prensiplerle aşkın bir varlık tarafından idare edilen dünya karmaşasının üstesinden, insani haz ve zevklerin kontrol altına alınarak gelinebileceği görüşü temel olarak uygulanabilir nitelikte görülmüş olacak ki bu anlayış, Hristiyanlık ile ortası bulunup İspanya'da devletin idaresi için paha biçilmez bir meşruiyet aracı hâline getirilmiştir. İngiltere ve İskoçya'da ise Lipsius'un canlandırdığı bu yeni stoacı öğretiler daha karmaşık bir biçime bürünür (Salmon, 1989: 199-225). İskoçya'da VI. James olarak bilinen İngiliz Kralı I. James, Lipsius'un fikirlerini Britanya'da elinden geldiğince yasaklamaya çalışmıştır.

Adaların değişik bir tarihsel tecrübeye sahip oluşu bu durumun detaylı bir analizinin yapılmasını bu yazı için olanaksız kılmaktadır. Kraliçe Elizabeth döneminden itibaren Sidney çevresinin etkin olduğu politik süreçte Lipsius ve diğer yazarlarca geliştirilen fikirler, saraya karşı tavır alan bu grup tarafından benimsendiği için kraliyet politikalarında pek rağbet görmez. Ayrıca Sidney ve devamındaki muhalif Essex grupları bu öğretilerle meşruiyet kazandırılmış fikirleri savunarak hem Elizabeth'e hem de James'e karşı çıkmışlar; ancak sonuçta başarısızığa uğrayarak kontrol altına alınmışlardır. Bunun sonucunda ise yeni stoacı fikirleri savunan düşünürlerin eserlerinde daha 
çok karamsar bir havadan bahsedilir olmuştur (McCrea, 1997: 31-39). Yani bu ülkelerde Lipsius'un üzerinde pek durmadığı ve daha felsefi konuları içeren ögeler öne çıkarılmıştır. Yukarıda değinildiği gibi bu ülkelerdeki tartışma, daha aktif bir politik yaşantıdan ziyade kraliyet çevresiyle özdeşleştirilmiş bürokratik bir yozlaşmadan kaçma ve erdemi stoacı bilgelik ağaçlarıyla bezenmiş çileci ve bireysel yaşantıda arama üzerine kurulmuştur. Aynı süreç Cromwell'in 1640'ı yıllarda İskoçya'yı istilasıyla İskoç yazarlarını da etkilemiştir. George Buchanan gibi ünlü İskoç yazarların elinde politik yaşantıda kralın hâkimiyetine karşı koymaya kadar giden stoacı felsefi-siyasi anlayış yerini, artan dini savaşlarla ve I. Charles'ın idamıyla sonuçlanan iç karışıklıklarla daha çok Epikürcülükle karışmış, stoacı içe dönüş reçeteleriyle dolu ve bu anlamda stoacılığın başka bir yorumuna tekabül eden bir anlayışa terk etmiştir (Allan, 2000: 214-219).

\section{Sonuç Yerine}

Toparlamak gerekirse özellikle konumuz dâhilinde Avrupa, on beşinci ve on altıncı yüzyıllarda etkilerini bugün dahi sürdüren antik çağ düşüncesinin yeniden incelenmesi olarak adlandırılabilecek bir tarihsel tecrübe neticesinde stoacılığı yeniden üretme ve öğretilerini uygulamaya geçirme yollarını aramıştır. Bunun hem dinsel hem de politik anlamda büyük etkileri olmuştur. Hem düşünsel bir mirastan yararlanılmış hem de dönemin politik karmaşasından doğmuş bir ihtiyaç neticesinde antik çağ metinlerine muazzam bir ilgi ortaya çıkmıştır. Justus Lipsius'un başını çektiği çeşitli isimler tarafından paylaşılmış bir ilgi sonucunda dönemin acil çözüm bekleyen sorunları Aristoteles ve Platon'un metafizik yönleri daha ağır basan önerileri yanında, stoacı diyebileceğimiz erdemlerle karşılanmaya çalışılmıştır. Lipsius'un örtük olarak Cicero'dan ve net bir şekilde Senaca-Tacitus ikilisinden çıkardığı tarih, politika ve askerî disiplin konuları felsefe ve retorik erdemlerinin yerini almaya başlamıştır. Bu başılıklar çeşitli yazarlar tarafından ele alınmış, tartışılmış, gözden geçirilmiş ve dönemin farklı politik yapılanmaları içerisinde değişik dönüşümlere neden olmuştur. Bu dönemden itibaren artan bir şekilde insan erdeminin salt bir felsefe öğretisinde değil, bunun yanında tarihsel olarak öğrenilen ve öğrenilenin etkin olarak kullanımını gerektiren bir anlayışta yattığına inanılmıştır. Devletleri idare eden yöneticiler bir yandan düzensizliği kontrol altına almayı stoacı tarihten öğrenmeye ve bunları daha merkezî yapılanmalar dâhilinde uygulamaya sevk edilirken; bu örgütlenmeler altında yaşayan insanlar ise zorluk ve karmaşaya göğüs germenin, itaat etmenin önemini yine stoacı felsefeden hareketle benimsemeye yönlendirilmişlerdir. Bu öğretilerin tarihsel önemi, bazen hikmet-i hükümet anlayışının içerisinde, bazen merkezî hükûmete karşı koymaya yönelik eylemlerde, bazen de dünyadan elini eteğini çekip erdemli olmayı kişinin kendi şiirsel bahçesinde bulma arayışında ortaya çıkan çok karmaşık, ancak oldukça ilginç ve zevkli bir süreçte aranmalıdır. 
Gerçekten de ülkemizde pek bilinmese de yeni stoacı tartışmaların Batı ülkeleri için yadsınamaz bir önemi vardır. On altıncı ve on yedinci yüzyıl yeni stoacıları üzerine yoğunlaşan akademik araştırmalar, daha geç dönemlerle ilgilenen uzmanlar için ilginç sonuçlar ortaya koyan bir araştırma konusu teşkil etmiştir. Buna göre Aydınlanma ve sonrasındaki birçok düşünürün yazılarında hâkim bir yeni stoacı etkiden söz edilir olmuştur. John Suart Mill, Adam Smith, Herder, Fichte, Hugo ve Carlyle gibi isimlerin fikirleri, Yeni Çağda ortaya çıkan bu yeni stoacı tartışmaların daha sonraki dönemlere nüfuzları olarak değerlendirilmiştir. Yirminci yüzyılda da farklı dönemlerdeki yorumlarına atıfla birtakım stoacı erdemlerin iki dünya savaşının yaralarını sarılabileceği ileri sürülmüştür. Jean Paul Sartre'ın varoluşçuluk felsefesinin de her noktada stoa düşüncesine göndermelerle dolu olduğu iddia edilmektedir (Olson, 1962: 4-9, 160-163). Günümüz çevreci ve ekoloji aktivistleri de stoa felsefesinin can damarını işaret eden "doğal uyum" düşüncesinden hareket ederler. 1990'lı yıllarda ise bazı yazarlar, dünyada hâkim olan ahlaki görecelik ve kuşkuculuk ile katı materyalizmden kurtulmanın, yeni stoacılığın değişik açılardan yorumlanmasıyla ortaya çıkacak öğretilerine sarılarak gerçekleşeceğini düşünmüşlerdir.' Aynı şekilde her türlü toplumsal sorunu uluslararası bir platformda çözme eğiliminde olan günümüz yaklaşımları da bu felsefeye eklemlenirler. Sovyet rejiminin çöküşüyle bütün dünya ülkelerine bir çözüm yolu olarak sunulan ve ABD'nin dünyaya yayma misyonunu üstlendiği güçler dengesini esas alan anayasal düzenin, temel olarak stoacıların savundukları ideal yönetimle benzeştiği savunulagelmiştir. ${ }^{2}$

Görüldüğü gibi ülkemizde pek dikkat çekmemiş olsa bile stoacı yaklaşımlar "yeni stoacılık" başlığı altında tarihsel olarak devamlı surette gündemde tutulmuş ve birçok somut gelişmenin ideolojik ya da teorik dayanağı hâline gelmiştir. ${ }^{3}$ Ancak, bu yazının genel çerçevesi içerisinde de ortaya konmaya çalışıldığı gibi, konuyu ilerlemeci bir zihniyetle bütün bağlamlarından koparılmış aşkın bir stoa bilgeliği etrafında işlemek mümkündür. Ancak stoacılığı, dinsel politik ve toplumsal olaylarla ilişkilendirilerek tarihsel yönden ele almak, bugüne kadar vurgulanmamış olan yeni özelliklere ve yorumlara ulaşılmasını kolaylaştıracaktır.

1 Bu konuyu Becker, eserinin değişik bölümlerinde etraflıca tartışmıştır. bk. Becker (1998). Güncel tartışmalar için bk. Sherman (2005).

3 Ahmet Davutoğlu'nun çalışmalarındaki değindiği kimi noktalar, Türkiye açısından istisna olarak kabul edilebilir. Konumuz bağlamında stoacı düşüncenin Batı düşünsel geleneğinde, özellikle "aksiyolojik sekülerleşmenin" ilk örneklerini ortaya koyması açısından merkezî konumuna ilişkin olarak bk. Davutoğlu (1994: 17-18, 40). 


\section{Kaynakça}

Allan, D. (2000). Philosophy and politics in later Stuart Scotland: Neo-stoicism, culture and ideology in an age of crisis, 1540-1690. Edinburgh: Tuckwell Press.

Becker, L. C. (1998). A new stoicism. Princeton, NJ: Princeton University Press.

Bouwsma, W. J. (1975). The two faces of humanism: Stoicism and augustinianism in renaissance thought. In Heiko A. Oberman and Thomas Bardy (Eds.), Itinerarium Italicum: The profile of the Italian Renaissance in the mirror of its European transformations (pp. 3-61). Leiden, Brill.

Brun, J. (1997). Stoa felsefesi (çev. M. Atııı). İstanbul: Iletişim Yayınları.

Burke, P. (1991). Tacitus, scepticism, and reason of state. In J. H. Burns \& M. Goldie (Eds.), Cambridge history of political thought 1450-1700 (pp. 479-99). Cambridge: Cambridge University Press.

Chew, A. (1950). Joseph Hall and neo-stoicism. PMLA, 65, 1130-1145.

Chew, A. (1988). Stoicism in Renaissance English literature: An introduction. New York: Peter Lang.

Colish, M. L. (1990). The stoic tradition from antiquity to the early middle ages (Vol. 2). Leiden: E. J. Brill.

Corbett, T. G. (1975). The cult of Lipsius: A leading source of early modern Spanish statecraft. Journal of the History of Ideas, 36, 139-152.

Davies, N. (2006). Avrupa tarihi (çev. Ed. M. A. Kılıçbay). İstanbul: İmge Kitapevi.

Davutoğlu Ahmet. (1994). Alternative paradigms: The impact of Islamic and Western weltanschaaungs on political theory. New York: University Press of America.

Devine, F. E. (1970). Stoicism on the best regime. Journal of the History of Ideas, 31, 323-336.

Lipsius, J. (1594). Two Books of Constancie Written in Latine, by Justus Lipsius. London.

_ (2004). Politica: Six Books of Politics and Political Instruction, (Ed. Jan Waszink). Assen: Royal Van Gorcum.

McCrea, A. (1997). Constant minds: Political virtue and the Lipsian paradigm in England, 1584-1650. Toronto: University of Torornto Press.

Oestreich, G. (1982). Neostoicism and the early modern state (D. McLintock, Trans.). Cambridge: Cambridge University Press.

Olson, R. G. (1962). An introduction to existentialism. New York: Dover Publications.

Salmon, J. H. M. (1980). Cicero and Tacitus in sixteenth-century France. The American Historical Review, 85, 307-331.

Salmon, J. H. M. (1989). Stoicism and Roman example: Seneca and Tacitus in Jacobean England. Journal of the History of Ideas, 50, 199-225.

Sherman, N. (2005). Stoic warriors: The ancient philosophy behind the military mind. Oxford: Oxford University Press.

Skinner, Q. (1977-8). Foundations of modern political thought (2 Vol.). Cambridge: Cambridge University Press.

Tillich, P. (1959). The courage to be. New Haven: Yale University Press.

Voogt, G. (1997). Primacy of individual conscience or primacy of the state? The clash between dirck volckertsz. Coornhert and Justus Lipsius. Sixteenth Century Journal, 28(4), 1231-1249.

Wolin, S. S. (2004). Politics and vision: Continuity and innovation in Western political thought. Princeton: Princeton University Press. 


\title{
Lessons From Antiquity: Neo-Stoicism In The Early Modern European Thought
}

\author{
M. Burak Özdemir*, Fatih Durgun ${ }^{* *}$
}

Keywords: Antiquity, Neo-Stoicism, Justus Lipsius, Seneca, Tacitus, Renaissance, Reformation.

\begin{abstract}
Although it has been supposed that Enlightenment debates on the writings of Aristoteles and Platon might have marginalised the intellectual and philosophical schools rooted in the Antiquity; Neo-Stoicism, as an authentic philosophical thought have become precisely determinant on the political and social envisions and projects throughout the early modern period. In Turkey, Neo-Stoicism has been deliberately ignored and neglected as a subject matter since it has been conventionally accepted that Stoic philosophy had not any significant place in different strands of transformations in European intellectual history. Another signifier of this phenomenon is the mere emphasis on the names of Plato or Aristotle in Turkey when the Antiquity and its legacy have been mentioned. Undoubdetly, we must consider the pejorative effects of the western thinkers behind this neglect. However, neither the Antiquity can be properly examined with sloppy references to Plato or Aristotle nor the European history in general can be presented as a re-formulation of the writings of both philosophers.

Historical process offers reliable evidence for this argumentation. Early Modern Europe witnessed the emergence of more centralised states as a consequence of sociopolitical, economic and religious turmoil. Since the Renaissance and Reformation, it has been commonly held that Stoic philosophy has offered much more substantial solutions to the problems of the crises in Western societies than other philosophical schools of the Antiquity. It can be argued that the discourses shaped by references to the thinkers identified with Neo-Stoicism steered the course of intellectual discussions as well as political and intellectual programmes in this period. Besides, the place and influence of Neo-Stoicism, as a resurgence of ancient Stocism, in the formation of early modern central states should be emphasized. The Antiquity and Christianity have been unalienable intellectual sources for western societies. Though the transformative, regulating and legitimising impacts of these traditions have been observed intensely at the times of crises, they have had undeniable place in nearly all

* Belfast Queen's Üniversitesi Tarih Bölümü Araştırma Görevlisi, m_burak19@hotmail.com

** Bilkent Üniversitesi Tarih Bölümü Araştırma Görevlisi, fatihd@bilkent.edu.tr
\end{abstract}


periodisations of European history. In that vein, both the intellectual activities and the eradication of the disorders in any segments of the society rougly up to the second half of the nineteenth century were commonly functional in the rejection of innovative ideas. In that sense, this paper concentrates on the increasing importance of Stoic and Neo-Stoic discourses in the context of European history particularly after the Renaissance. Actually, several transformative factors aroused certain and great interest in the Antiquity in this period.

However, it is essential to indicate that the architects of interpretative abundance did not principally seek for a reconstruction of a new world. Conversely, they cast about the existing social, political and economic perversions by virtues inherited from the past. In other words, the Antiquity had various intellectual potentialities to find solutions to the problems of every age. The past and the ancient have always been regarded as more valuable than the future and the modern. If it is really necessary to speak of an innovation, this did not emerge by the existence of new ideas. The revival of Stoicism and the concentration on Stoic texts in the early modern period have been substantiated in different ways and methods. In this process, several earlymodern intellectuals in various European countries have emphasized and underlined the different sides of Stoic tradition in response to the distresses and turmoils of the period. But, it is possible generally to talk about some great names, which inspired this interest. In this sense, Cicero, Tacitus, Seneca, Aurelius, Epictetus and Boethius can be counted as the most significant figures of Stoic philosophy. The writings of these thinkers were scrutinised very carefully and their contents were consciously reproduced. For example, according to Peter Burke, at least hundred writers of early modern period between the years of 1580-1700 did make comments on the thought of Tacitus and applied some points in his thought systematically to the urgent problems. Consequently, Tacitus represented one of the most striking sources of Neo-Stoic virtues either as a historian or a political theorist.

Amongst the Neo-Stoic thinkers of early modern period, Justus Lipsius comes forth as the most important figure as a contemporary of Erasmus. Well acquainted with Catholicism, Calvinism, Lutheranism and Antiquity, Lipsius had a sufficient intellectual backdrop for becoming a coterie of many leading figures of the time. Like Erasmus, the divisive effects of discussions and conflicts about Christianity stimulated Lipsius in the early modern period. For him, Christianity should have been a unifying value for the European thought, rather than a constituent of constant warfare and endless disagreements. The point where he differed from Erasmus lay in his suggestions for the resolution of common problems of the day. His primary concern was to reconcile the religious fervour and the social disorder by way of a learned argument about what was good in Christianity and Antiquity. Lipsius dedicated himself to a re-interpretation of what one may call as an age-old treasure of Stoicism. He made much use of the 
overall emphasis of Stoic thinkers on the need of a rational construction of virtuous, peaceable and tranquil life. Actually, Lipsius' essential concern can be detected in his vacillations about Stoic virtues. All in all, the importance of Justus Lipsius lay not only in the re-assessment of the Stoic tradition in the early modern period, but in the transmission of ideas and available sources about Stoicism to coming generations as well.

Unsurprisingly then, Neo-Stoicism has deeply influenced thoughts and writings of Enlightenment and post-Enlightenment thinkers such as Adam Smith, Fichte and Herder. Gerhard Oestrich has made the most controversial evaluation about the role played by Neo-Stoicism in the emergence of the modern states. According to Oestrich, Neo-Stoic interpretation has emphasized the inherent conservative approaches and attitudes in Stoic tradition to offer solutions to the complicated problems of the period. It has become influential in the formation of centralised political establishments in the countries like France and prepared suitable intellectual infrastructure for others. Today the environmentalists and ecologists have been motivated by "natural rapport" notion of Stoicism. Philosophers such as Martha Nussbaum and Nancy Sherman have also shown a lively interest in the conciliatory and explanatory potential of Stoic philosophy for the interpretation of contemporary world and events. Thus, a discussion of an early-modern figure who engaged in similar scholarly endeavours in an environment quite different from ours might be deemed as an interesting and inspiring intellectual effort. 